\title{
THE EFFICIENCY OF USING SALICYLIC ACID, GIBBERELLIC ACID AND SILICON, ON THE PRODUCTIVITY OF THE MAIZE PLANT (ZEA MAIZE L.) UNDER SALT- AFFECTED SOIL CONDITIONS . \\ El-Kamar, Faten A. ; Kh. A. H. Shaban and Rama T. Rashad \\ Soils \& Water and Environ. Res. Inst., Agric. Res. Center, Giza, Egypt. \\ Khaledshaban2004@yahoo.com
}

\begin{abstract}
Soil salinity is one of the important factors affecting new reclaimed Sahl El-Tina soil at North Sinai. To face this problem, two field experiments were carried out during the two summer growing seasons of 2011 and 2012 to investigate the effect of foliar application of salicylic acid (SA) $\left(50-100 \mathrm{mg} \mathrm{L}^{-1}\right)$, Gibberllic acid (GA3) $(100-200$ $\left.\mathrm{mg} \mathrm{L}^{-1}\right)$ and potassium silicate $(\mathrm{Si})\left(50-100 \mathrm{mg} \mathrm{L}^{-1}\right)$ on the straw, grain yields and the mineral contents of maize (Zea maize L. CV. single hybrid 10) grown in a salt affected soil. Plants were sprayed by the each of the three afore materials at 30,45 and 60 days from sowing. It was found that the application of the three materials increased both the straw and grain yields significantly. $\mathrm{Na}^{+}$concentration in leaves and grains was inhibited while $\mathrm{N}, \mathrm{Mg}, \mathrm{Fe}, \mathrm{Mn}$ and $\mathrm{Cu}$ were stimulated. The chlorophyll pigmented ( $a$ and $b$ ) and carotenoid contents were significantly increased due to application of $\mathrm{SA}, \mathrm{Si}$ and GA3. These results suggested that SA, GA3 and $\mathrm{Si}$ can be used as potential growth regulators to improve salinity stress resistance.

keywords: Maize, Salicylic acid, Gibberellic acid, Silicon.
\end{abstract}

\section{INTRODUCTION}

Crops grown in arid and semi-arid regions are often exposed to adverse environmental factors such as high soil salinity, Gunes et al 2007). Salinity inhibits the seed germination, height, fresh and dry weights of the roots and shoots, chlorophyll and carotenoid contents of wheat while increased the proline content, Levent et al (2007).

Salinity may increase, decrease, or have no effect on the micronutrients (e.g. $\mathrm{Cu}, \mathrm{Fe}, \mathrm{Mn}, \mathrm{Mo}$ and $\mathrm{Zn}$ ) concentration in plant shoots (Bengu, 2012).

When plants are subjected to stress conditions, highly reactive activated oxygen species ROS( cytotoxic species) are produced that can seriously disrupt normal metabolism through oxidative damage to lipids, protein , nucleic acids and chlorophyll breakdown, Leventet al (2008 b).

The excess salt in the soil affects the plant growth either through osmotic inhabitation of water uptake by roots or specific ion effects. Salt stress leads to metabolic changes, like loss of chloroplast activity, decrease in photosynthetic rate and increase in photorespiration rate which in turn leads to the increased production of ROS (Parida and Das, 2005).

The exogenous application of plant growth regulators (PGRs) such as salicylic (SA) and gibberellic acids (GA3) was found to alleviate the adverse effects of salinity stress on the above mentioned parameters (Parida and 
Das, 2005 and Bengu, 2012). PGRs are responsible for seed germination, stem elongation, leaf expansion, and flowering. They also prevent chlorophyll breakdown and decreases ROS levels that lead to cell death (Wen et. al., 2010). However, the use of PGRs must be under control. They may cause organ damages, including the brain, alarming toxicity to the breast, lung, kidney, liver and neurotoxicity of experiment mice (Troudia et. al. 2012). A combination of GA3 with a high concentration of EDTA causes severe soil and ground water pollution, (Hadi, et. al., 2010). Bejaoui (1989) concluded that the effects of GA3 may be caused by the activation of special enzymes which participate in the RNA and protein synthesis. Levent et al (2008) found that the foliar application of GA3 counteracted the accumulation of proline which maintained membrane permeability and increased macro and micronutrient levels. GA3 reduced the effect of salinity on the germination, growth and yield of maize, (Chowdhury and Sarwar, 2000).

Salicylic acid (SA); a hormone-like plant phenolic, is widely distributed in plants. It plays an important role in the regulation of plant growth and development (Klessing and Malamy, 1994). Bhupinder and Usha, (2003) and Gunes et al. (2007) found that SA application inhibited $\mathrm{Na}^{+}$accumulation but stimulated $\mathrm{N}, \mathrm{P}, \mathrm{K}, \mathrm{Mg}, \mathrm{Fe}, \mathrm{Mn}$ and $\mathrm{Ca}$ uptake. An increase in the ion constriction of $\mathrm{K}$ and $\mathrm{Ca}$ in plants under salt stress could ameliorate the deleterious effect of salinity on growth and yield, Alteration of mineral uptake due to the SA application may be one mechanism for the alleviation of salt stress, (Levent, et al. 2007). Kothule et al. (2003) showed that salicylic acid (SA) at (200 mg L-1) was the most effective in increasing seed yield per ha and harvest index of soybean plant. Hasan and Mohaddeseh (2011) indicated that vegetative growth of maize was improved by increasing SA concentration up to $200 \mathrm{mg} \mathrm{L}^{-1}$. The highest amount of SA application was accompanied with $38.66 \%$ increase in chlorophyll concentration in the leaves. Gunes et al. (2007) reported that the SA could be used to improve plant salinity tolerance. Yamane et al. (2004) reported that the reduction in chlorophyll by salt stress is due to induced injury in chloroplasts that is dependent on the light. (Mady, 2009) found that the foliar application of SA effectively had improved $\mathrm{N}, \mathrm{P}, \mathrm{K}, \mathrm{Fe}, \mathrm{Zn}$ and $\mathrm{Mn}$ content in tomato leaves compared with those of the control plants in two seasons.

Silicon ( $\mathrm{Si}$ ) is abundant in soil and is the major constituent of many plants, but its role in the plant biology is poorly understood (Naeem, et al. 2010). Improvement of salt tolerance by the addition of Si has been reported for maize and wheat where it was found to correct to some extent the negative effects of salinity on growth, yield, nutrients uptake or photosynthetic activity, (Moussa, 2006; Mukkram et al., 2006 and Pei et al., 2010). Liang et al (2003) reported that the addition of Si to salt treated barley, significantly increased super oxide dismutase (SOD) activity in barley roots. (Hanafy et al., 2008) found that the lowest level of Si $\left(250 \mathrm{mg} \mathrm{L}^{-1}\right)$ significantly increased all the studied growth parameters of wheat plants, while all levels of $\mathrm{Si}$ significantly increased the number of spikes and grains as well as grains yield compared with the control non-sprayed plants. Gharib and Hanafy (2005) noted that, Si foliar application enhanced $\mathrm{N}$ and $\mathrm{K}$ concentrations in pea shoots and played an important role in improving $\mathrm{P}$ nutrition. 
A number of possible mechanisms are proposed through which silicon may increase the salinity tolerance in plants, e.g. improving water status (Romero et al. 2006), increasing photosynthetic activity and ultring structure of leaf organo-celles, (Shu and Lui, 2001) or by H- ATPase (Liang et al 2005).

Maize as an important cereal crop in Egypt, its cultivation has been recently extended to the newly reclaimed soil to meet the increasing population. Therefore, the aim of this study was to investigate the effect of SA; GA3; and Si foliar application on the yield and nutrients content of maize grown in salt affected soil.

\section{MATERIALS AND METHODS}

Two field experiments were conducted at Sahl El-Tina, North Sinai Governorate during two summer seasons 2011 and 2012, to study the effect of foliar application salicylic acid (AS) ; Gibbrillic acid (GA) and Silicon (Si) on maize plant grown in salt - affected soil. Some chemical and physical characteristics of studied soil are presented in Table (1). Treatments were designed as follows 1) control (without any treatment); 2) $50 \mathrm{mg} \mathrm{I}^{-1} \mathrm{SA}$; 3) 100 $\mathrm{mg} \mathrm{l}^{-1} \mathrm{SA}$; 4) $100 \mathrm{mg} \mathrm{l}^{-1} \mathrm{GA}$, 5) $200 \mathrm{mg} \mathrm{l}^{-1} \mathrm{GA}$; 6) $50 \mathrm{mg} \mathrm{l}^{-1} \mathrm{Si}$; 7) $100 \mathrm{mg} \mathrm{l}^{-1}$ $\mathrm{Si}$. Treatments were arranged in a randomized complete block design with four replicates.

Grains of maize (Zea mays L.) Varity of single hybrid 10 supplied by the Maize Department, Field Crop Research Institute were sown on $15^{\text {th }}$ and $20^{\text {th }}$ may 2011 and 2012, respectively.

Calcium super phosphate was added at a rate of $50 \mathrm{~kg} \mathrm{P}_{2} \mathrm{O}_{5} \mathrm{fed}^{-1}$ during soil preparation. Nitrogen was applied in a rate $100 \mathrm{~kg} \mathrm{~N} \mathrm{fed}^{-1}$ as urea in three equal dose after 21; 45 and 60 days from planting. Potassium sulphat was added at a rate of $100 \mathrm{~kg} \mathrm{~K}_{2} \mathrm{O}$ fed ${ }^{-1}$ in two doses after 30 and 50 days from planting. SA, GA3 and Si were foliar applied after 30, 45 and 60 days from sowing. All cultural practices for growing maize were done as recommended. Two leaves of four randomly chosen ten plants per replicated after 70 days from planting were collected from mid- sections of the plants in order to minimize age affects to determine it is chlorophyll and nutrients contents. At maize harvest (120 days) the total weights of ears and straw were recorded. Ears and straw were left for 15 days to reach normal air dryness (above $11 \%$ moisture) to support grains. Grain yield $\mathrm{kg} \mathrm{fed}^{-1}$ and 100 grain $(\mathrm{g})$ weight were recorded.

Soil analyses:

Particle size distribution was determined by the Pipette method (Piper 1950) and $\mathrm{CaCO}_{3}$ content was determined by Calcimeter (Page et al. 1982). Soil organic matter was determined by the Walkly and Black method as described by Page et al (1982). Soil pH was measured using $\mathrm{pH}$ meter in soil: water suspension (1: 2.5) described by Jackson (1967). Total soluble salt expressed as EC dSm${ }^{-1}$ was measured in soil past extract. Available $\mathrm{N}$ was extracted from soil using $2 \mathrm{~N} \mathrm{KCl}$ solution and measured according to the modified Kjeldahel method. Available $\mathrm{P}$ was extracted by $0.5 \mathrm{M}$ sodium bicarbonate and determined calorimetrically according to Olsen method as 
described by Jackson (1967). Available K was determined using the flame photometer. Available micronutrients were extracted by Diethyline tetra amin penta Acitic acid (DTPA) according to Soltan, (1985) were determined by using Atomic Absorption (model GBC 932). Soil chemical physical properties show in Table (1).

Table (1). Physical and chemical properties of the investigated soil.

\begin{tabular}{|c|c|c|c|c|c|c|c|c|c|}
\hline $\begin{array}{l}\text { Coarse } \\
\text { sand }(\%\end{array}$ & \begin{tabular}{l|l}
$\%)$ & \\
\end{tabular} & $\begin{array}{l}\text { Fine } \\
\text { Sand (\%) }\end{array}$ & $\begin{array}{l}\text { Silt } \\
(\%)\end{array}$ & $\begin{array}{l}\text { Clay } \\
(\%)\end{array}$ & & $\begin{array}{c}\text { Textural } \\
\text { class }\end{array}$ & $\begin{array}{l}\text { O.M } \\
(\%)\end{array}$ & & $\begin{array}{c}\text { CaCO3 } \\
(\%)\end{array}$ \\
\hline 24.4 & & 52.6 & 10.7 & 12.3 & & Sandy & 0.51 & & 8.20 \\
\hline \multirow{2}{*}{$\begin{array}{c}\mathrm{pH} \\
(1: 2.5)\end{array}$} & \multirow{2}{*}{$\begin{array}{c}E C \\
\left(\mathrm{dSm}^{-1}\right)\end{array}$} & \multicolumn{4}{|c|}{ Cations meq $^{-1}$} & \multicolumn{4}{|c|}{ Anins $\mathrm{mq} / \mathrm{l}$} \\
\hline & & $\left.n^{-1}\right)$ & & $\mathrm{N}^{+}$ & $\mathrm{K}^{+}$ & $\mathrm{CO}_{3}{ }^{-}$ & $\mathrm{CO}_{3}{ }^{--}$ & $\mathrm{Cl}^{-}$ & $\mathrm{SO}_{4}^{--}$ \\
\hline 8.32 & $8.7 \mathrm{C}$ & 11. & \begin{tabular}{|l|l|}
16 & 16.34 \\
\end{tabular} & 55.44 & 1.72 & nil & 5.95 & 43.07 & 37.98 \\
\hline
\end{tabular}

Available nutrients $(\mathrm{mg} \mathrm{kg}$ )

\begin{tabular}{|c|c|c|c|c|c|}
\hline \multicolumn{3}{|c|}{ Macronutrients } & \multicolumn{3}{c|}{ Micronutrients } \\
\hline $\mathbf{N}$ & $\mathbf{P}$ & $\mathbf{K}$ & $\mathbf{Z n}$ & $\mathbf{F e}$ & $\mathbf{M n}$ \\
\hline 48 & 6.1 & 190 & 2.1 & 3.1 & 4.3 \\
\hline
\end{tabular}

\section{Plant analyses:}

The oven dried plant part samples were ground, $0.5 \mathrm{~g}$ of each sample was digested using $\mathrm{H}_{2} \mathrm{SO}_{4}^{-}, \mathrm{HClO}_{4}$ mixture according to the methods described by Chapman and Pratt (1961).The plant content of N, P, K, Fe, Mn, Zn and Cu was determined in plant digestion using the methods described by Jackson (1967), Cottenie et al. (1982) and Black (1965). Fe, Mn, and $\mathrm{Zn}$ were determined by using Atomic Absorption (model GBC 932). $\mathrm{Na}$ and $\mathrm{K}$ content of the leaf analyzed with the flame photometer by the Versente method (Soliman and Doss, 1992)

Data were statistically analyzed according to Snedecor and Cochran (1990). Photosynthetic pigments (chlorophyll $a+b$ ) were measured in fresh leaf samples. Leaf samples (0.5) were homogenized with acetone $(90 \mathrm{v} / \mathrm{v})$, filtered and make up to a final volume of $50 \mathrm{ml}$. Pigment concentration was calculated from the absorbance of extract at 663,645 and $470 \mathrm{~nm}$ using the formula (Lichtonthaler 1987).

\section{RESULTS AND DISCUSSION}

\section{Grain and straw yield.}

Data presented in Table (2) show both the grains and straw yields as affected by spraying SA, GA3 and Si applied at different rates. Analysis of variance revealed significant effect of three materials on increasing grain and straw yields of maize plants. The highest grain and straw yields were achieved when the plants were sprayed with $100 \mathrm{mg} \mathrm{l}^{-1} \mathrm{SA}$. Spraying plants with $200 \mathrm{mg} \mathrm{l}^{-1} \mathrm{GA}_{3}$ resulted in significantly higher grain and straw yields than the corresponding ones achieved due to spraying with $100 \mathrm{mg} \mathrm{I}^{-1}$ one. Also, when plant received $100 \mathrm{mg} \mathrm{I}^{-1} \mathrm{Si}$ the straw and grain yields were higher compared with received $50 \mathrm{mg} \mathrm{I}^{-1} \mathrm{Si}$. The relative increases in grain yield were $27.8 ; 27.16$ and $22.15 \%$ respectively and corresponding to $26.6 ; 22.00$ 
and $20.6 \%$ in straw yield for the treatments $100 \mathrm{mg} \mathrm{I}^{-1} \mathrm{SA} ; 100 \mathrm{mg} \mathrm{I}^{-1} \mathrm{Si}$ and $200 \mathrm{mg} \mathrm{l}^{-1} \mathrm{GA} 3$, respectively. Growth reduction under saline condition has been well documented in various plants by many researchers such as Bengu (2012). Alleviated the deleterious affects of salinity by SA, GA3 and Si was studied by many author. Levent et al (2007), Gunes et al. (2007) and Fahad and Asha, (2012), pointed out that addition of SA to maize plants grown in salt affected soil was significantly increased dry matter yield. Increases in dry matter and yield of salt stressed plant in response to SA my be related to induction of antioxidant response and protective role of membranes that increase the tolerance of plant to damage (Gunes, et al. 2007). Levent et al. (2008) clear that foliar application of GA3 counter acted some of the adverse effect of salinity in maize plant with the accumulation of proline which maintained membrane permeability. Spraying with GA3 caused a significant increase in wheat grain yield under salt stress (Iqbal and Ashraf 2010). This effect of Si foliar allocation on maize yield under soil salinity is in agreement with the finding of Moussa (2006) who stated that oxegaus application of $\mathrm{Si}$ increased shoots and dry weight of maize plants grown in saline medias. They attributed the effect of $\mathrm{Si}$ on plant growth under soil salinity may be to role of membranes that increase the tolerance of plant to damage. In this respect, Hanafy et al. (2008) reported that silicon as a foliar application (50 or $100 \mathrm{mg} \mathrm{l}^{-1}$ ) increased grain yield of wheat grown under saline condition. They refereed that to increases in plant water status and chlorophyll content.

Table (2). Effects of salicylic acid, gibbrillic acid and silicon on grain and straw yield of maize grown under saline soil conditions.

\begin{tabular}{|c|c|c|c|}
\hline Treatments & $\begin{array}{c}\text { Grain yield } \\
\left(\mathrm{kg} \mathrm{fed}^{-1}\right)\end{array}$ & $\begin{array}{c}\text { Straw yield } \\
\left(\mathrm{kg} \mathrm{fed}^{-1}\right)\end{array}$ & 100 seed weight $(g)$ \\
\hline Control & 2194 & 3147 & 30.10 \\
\hline SA $50\left(\mathrm{mg} \mathrm{l}^{-1}\right)$ & 2535 & 3410 & 32.21 \\
\hline SA $100\left(\mathrm{mg} \mathrm{I}^{-1}\right)$ & 2805 & 3719 & 33.81 \\
\hline Si $50\left(\mathrm{mg} \mathrm{l}^{-1}\right)$ & 2525 & 3325 & 31.80 \\
\hline Si $100\left(\mathrm{mg} \mathrm{l}^{-1}\right)$ & 2790 & 3620 & 32.30 \\
\hline GA3 $100\left(\mathrm{mg} \mathrm{I}^{-1}\right)$ & 2450 & 3396 & 31.50 \\
\hline GA3 200(mg l-1) & 2691 & 3590 & 31.8 \\
\hline L. S. D. at $5 \%$ & 195 & 170 & 1.10 \\
\hline
\end{tabular}

The values are means of two seasons.

\section{Macronutrients concentration in leaves and grains.}

Data presented in Tables ( 3 \&4)) show that the macronutrients $(\mathrm{N}, \mathrm{P}, \mathrm{K}$ and $\mathrm{Mg}^{++}$) concentrations in maize leaves and grains were significantly, except $\mathrm{Ca}^{++}$was no significant as affected with foliar application of $\mathrm{SA}, \mathrm{Si}$ and GA3 respectively. The highest value of $\mathrm{N}, \mathrm{K}, \mathrm{Ca}^{++}$and $\mathrm{Mg}^{++}$ concentration in leaves was $2.50 \%, 2.90 \%, 0.50 \%$ and $0.35 \%$ for $\mathrm{Si}(100$ $\mathrm{mg} \mathrm{L}^{-1}$ ) foliar application, respectively, while the highest value of $\mathrm{P}$ concentration in leaves was $0.63 \%$ for AG3 $\left(100 \mathrm{mg} \mathrm{L}^{-1}\right)$ foliar application. On the other hand, the highest value of $\mathrm{N}, \mathrm{Ca}^{++}$and $\mathrm{Mg}^{++}$concentration in grain were $1.90 \%, 0.33 \%$ and $0.19 \%$ respectively for Si foliar application of rate $100 \mathrm{mg} \mathrm{L}^{-1}$, while the highest $\mathrm{P}$ value was $0.48 \%$ for GA3 foliar 
application by rate of $\left(200 \mathrm{mg} \mathrm{L}^{-1}\right)$ and the highest value of $\mathrm{K}$ concentration in grain was $0.69 \%$ for SA foliar application with rate $100 \mathrm{mg} \mathrm{L}^{-1}$. From these results it could be concluded that $\mathrm{N}, \mathrm{P}, \mathrm{K}, \mathrm{Ca}^{++}$and $\mathrm{Mg}^{++}$concentration in leaves and grains increased with increasing rate foliar application of $\mathrm{Si}, \mathrm{SA}$ and GA3, respectively. These results are agreement by Singh et al (2006) reported that the application of silicon rate of $180 \mathrm{~kg} \mathrm{ha}^{-1}$ caused increased $\mathrm{N}$ and $\mathrm{P}$ in the grain and straw of rice.

Table (3). Effect of salicylic acid, Gibbirellic acid and Silicon on macronutrients (\%) in leafs of maize plants growing under saline soil conditions (the mean values of two seasons).

\begin{tabular}{|l|c|c|c|c|c|}
\hline \multicolumn{1}{|c|}{ Treatments } & $\mathbf{N}$ & $\mathbf{P}$ & $\mathbf{K}$ & $\mathbf{C a}^{++}$ & $\mathbf{M g}^{++}$ \\
\hline Control & 1.62 & 0.39 & 1.80 & 0.40 & 0.31 \\
\hline SA 50 (mg l-1 & 2.10 & 0.40 & 2.20 & 0.45 & 0.45 \\
\hline SA 100 (mg l-1) & 2.40 & 0.45 & 2.80 & 0.49 & 0.51 \\
\hline Si 50 (mg l-1) & 1.98 & 0.42 & 2.50 & 0.46 & 0.41 \\
\hline Si 100 (mg l-1) & 2.5 & 0.45 & 2.90 & 0.50 & 0.53 \\
\hline GA3 100 (mg l-1) & 2.20 & 0.63 & 2.30 & 0.42 & 0.39 \\
\hline GA3 200(mg l-1) & 2.35 & 0.61 & 2.60 & 0.48 & 0.42 \\
\hline L. S. D. at 5 \% & 0.30 & 0.065 & 0.21 & $\mathrm{~ns}$ & 0.05 \\
\hline
\end{tabular}

Table (4). Effect of salicylic acid, gibbirellic acid and silicon on macronutrients (\%) in maize grain under saline soil conditions combined (the mean values of two seasons).

\begin{tabular}{|l|c|c|c|c|c|}
\hline \multicolumn{1}{|c|}{ Treatments } & $\mathbf{N}$ & $\mathbf{P}$ & $\mathrm{K}$ & $\mathrm{Ca}^{++}$ & $\mathrm{Mg}^{++}$ \\
\hline Control & 1.25 & 0.29 & 0.39 & 0.21 & 0.09 \\
\hline SA 50 (mg l-1 & 1.56 & 0.33 & 0.60 & 0.25 & 0.14 \\
\hline SA 100 (mg l-1) & 1.60 & 0.35 & 0.69 & 0.31 & 0.15 \\
\hline Si 50 (mg l-1) & 1.80 & 0.31 & 0.54 & 0.30 & 0.19 \\
\hline Si 100 (mg l-1) & 1.90 & 0.30 & 0.60 & 0.33 & 0.19 \\
\hline GA3 100 (mg l-1) & 1.60 & 0.45 & 0.55 & 0.27 & 0.17 \\
\hline GA3 200(mg l-1) & 1.72 & 0.48 & 0.59 & 0.28 & 0.19 \\
\hline L. S. D. at 5 \% & 0.12 & 0.08 & 0.08 & 0.09 & 0.01 \\
\hline
\end{tabular}

Levent et al (2008) found that the foliar application of GA3 treatment increase macro and micronutrients levels.

Concerning that the addition of $\mathrm{SA}, \mathrm{Si}$ and $\mathrm{GA} 3$ increased $\mathrm{Mg}^{++}$ concentration in maize leaves and grains compared with control. The $\mathrm{Mg}^{++}$ concentration in leaves and grains increases of value with increasing of rates (100 mg L $\mathrm{m} \mathrm{SA}^{-1} \mathrm{~S} 100 \mathrm{mg} \mathrm{L}^{-1} \mathrm{Si}$ and $200 \mathrm{mg} \mathrm{L}^{-1} \mathrm{GA} 3$ ). These results are agreement with Gunes et al (2007) showed that the SA foliar application increased $\mathrm{Mg}^{++}$content in stressed maize leaves. Hanafy et al (2008) stated that $\mathrm{Mg}$ concentration in wheat grains and straw grown increased when plant treated with Si foliar application.

Sodium concentration in leaves and grains maize plants.

Data presented in Table (5) show that the foliar application of SA, Si and GA3 on $\mathrm{Na}^{+}$concentration in leaves and grains maize plants was significantly decreased as compared to control. The highest value of $\mathrm{Na}^{+}$concentration was $0.55 \%$ for leaves and $0.71 \%$ for grains of untreated plants (control). 
Table (5). Effect of salicylic acid, gibberellic acid and silicon on $\mathrm{Na}^{+}(\%)$ concentration in maize plants leaves and grains grown under saline soil conditions(the mean values of two seasons).

\begin{tabular}{|l|c|c|}
\hline \multicolumn{1}{|c|}{ Treatments } & Leaves & Grains \\
\hline Control & 0.55 & 0.71 \\
\hline SA 50 (mg l-1 & 0.32 & 0.58 \\
\hline SA 100 (mg l-1) & 0.28 & 0.49 \\
\hline Si 50 (mg l-1 ) & 0.28 & 0.46 \\
\hline Si 100 (mg l-1) & 0.24 & 0.38 \\
\hline GA3 100 (mg l-1) & 0.35 & 0.50 \\
\hline GA3 200(mg l-1) & 0.30 & 0.42 \\
\hline L. S. D. at 5 \% & 0.11 & 0.15 \\
\hline
\end{tabular}

The corresponding relative decreases values of $\mathrm{Na}^{+}$concentration in leaves was 41.81 and $49.10 \%$ for SA rate $\left(50\right.$ and $\left.100 \mathrm{mgL}^{-1}\right) ; 49.10$ and $56.36 \%$ for $\mathrm{Si}$ of rate $\left(50\right.$ and $\left.100 \mathrm{mg} \mathrm{L}^{-1}\right)$ and 36.36 and $45.54 \%$ for GA3 of rate $\left(100\right.$ and $\left.200 \mathrm{mgL}^{-1}\right)$ respectively, compared with control. Also, the relative decreases values of $\mathrm{Na}^{+}$concentration in grains was 18.31 and 30.98 $\%$ for SA rate $\left(50\right.$ and $100 \mathrm{mgL}^{-1}$ ); 35.21 and $46.47 \%$ for Si of rate $(50$ and $\left.100 \mathrm{mg} \mathrm{L}^{-1}\right)$ and 29.58 and $40.84 \%$ for GA3 of rate $\left(100\right.$ and $\left.200 \mathrm{mgL}^{-1}\right)$ respectively, compared with control. The decrease value of $\mathrm{Na}^{+}$as affected by SA, Si and GA3 may explain reflect to the increased antioxidant activity, on the growth of salt stressed maize plants, (Farahbakhsh and Shamsaddin, 2010). These results are agreement by Gunes et al (2007) found that the foliar application of SA caused decreased $\mathrm{Na}^{+}$content of maize tissues under salinity. Levent et al (2008) pointed that treating maize plants grown under saline stressed soil with $\mathrm{GA} 3$ has decreased its $\mathrm{Na}+$ contents in straw and root. Liang et al (2003) stated that addition of Si was found to reduce sodium but increases potassium concentration in shoots and roots of salt stress barley. Thus, Si enhanced salt tolerance is planting attributed to selective uptake and transport of potassium and sodium by plant.

Micronutrients content in leaves and grains of maize.

Effect of foliar application SA, Si and GA3 at different rates on Fe, Mn, $\mathrm{Cu}$ and $\mathrm{Zn}$ concentration in leaves and grains maize plants were positive effect under saline soil conditions. Data presented in Tables (6 \&7) show that the foliar application of $\mathrm{SA}, \mathrm{Si}$ and $\mathrm{GA} 3$ on $\mathrm{Fe}, \mathrm{Mn}$ and $\mathrm{Cu}$ concentration in leaves and grains maize plants were significantly increase, while the $\mathrm{Zn}$ concentration in both leaves and grains was no significant. The highest mean values of $\mathrm{Fe}, \mathrm{Zn}, \mathrm{Mn}$ and $\mathrm{Cu}$ concentration in leaves maize plants were $151,62,105$ and $5.2 \mathrm{mg} \mathrm{kg}^{-1}$ respectively, for planted treated with foliar application of $\mathrm{Si}\left(100 \mathrm{mg} \mathrm{L}^{-1}\right)$. Also, the highest mean values $\mathrm{Fe}, \mathrm{Zn}, \mathrm{Mn}$ and $\mathrm{Cu}$ concentration in grains maize plants were $78.00 \mathrm{mg} \mathrm{L}^{-1}$ for $\mathrm{Fe}$ of plants treated with $\mathrm{Si}\left(100 \mathrm{mg} \mathrm{L}^{-1}\right) ; 48.00 \mathrm{mg} \mathrm{L}^{-1}$ for $\mathrm{Zn}$ of plants treated with GA3 $\left(100 \mathrm{mg} \mathrm{L}^{-1}\right) ; 36.00 \mathrm{mg} \mathrm{L}^{-1}$ for Mn of plants treated with GA3 $\left(200 \mathrm{mg} \mathrm{L}^{-1}\right)$ and $2.80 \mathrm{mg} \mathrm{L}^{-1}$ for $\mathrm{Cu}$ of plants treated with $\mathrm{SA}\left(100 \mathrm{mg} \mathrm{L}^{-1}\right)$, respectively. Corresponding relative increases mean values of $\mathrm{Fe}, \mathrm{Zn}, \mathrm{Mn}$ and $\mathrm{Cu}$ 
concentration in leaves maize plants as affected by foliar application of SA at different rates (50 and $100 \mathrm{mg} \mathrm{L}^{-1}$ ) were 23.81 and $33.33 \%$ for $\mathrm{Fe}$; 3.57 and $7.14 \%$ for $\mathrm{Zn} ; 25$ and $39.70 \%$ for $\mathrm{Mn}$ and 44.12 and $50.00 \%$ for $\mathrm{Cu}$, respectively, compared with control.

Table (6). The effect of salicylic acid, Gibbrillic acid and silicon on micronutrients $\left(\mathrm{mg} \mathrm{kg}^{-1}\right)$ in leaves of maize plant combined (the mean values of two seasons).

\begin{tabular}{|c|c|c|c|c|}
\hline Treatments & $\mathrm{Fe}$ & $\mathrm{Zn}$ & Mn & $\mathrm{Cu}$ \\
\hline Control & 105.00 & 56.00 & 68.00 & 3.40 \\
\hline SA $50\left(\mathrm{mg} \mathrm{l}^{-1}\right)$ & 130.00 & 58.00 & 85.00 & 4.90 \\
\hline SA $100\left(\mathrm{mg} \mathrm{l}^{-1}\right)$ & 140.00 & 60.00 & 95.00 & 5.10 \\
\hline Si $50\left(\mathrm{mg} \mathrm{l}^{-1}\right)$ & 118.00 & 59.00 & 99.00 & 4.10 \\
\hline Si $100\left(\mathrm{mg} \mathrm{l}^{-1}\right)$ & 151.00 & 62.00 & 105.00 & 5.20 \\
\hline GA3 $100\left(\mathrm{mg} \mathrm{l}^{-1}\right)$ & 120.00 & 58.00 & 80.00 & 4.40 \\
\hline GA3 $200\left(\mathrm{mg} \mathrm{l}^{-1}\right)$ & 125.00 & 61.00 & 91.00 & 4.80 \\
\hline L. S. D. at $5 \%$ & 10.21 & ns & 13.42 & 0.42 \\
\hline
\end{tabular}

Table (7). The effect of salicylic acid, Gibbrillic acid and silicon on micronutrients (mg kg-1) in maize grain combined over the two seasons.

\begin{tabular}{|l|c|c|c|c|}
\hline \multicolumn{1}{|c|}{ Treatments } & Fe & Zn & Mn & Cu \\
\hline Control & 53.00 & 42.00 & 24.00 & 1.80 \\
\hline SA 50 (mg l-1 & 65.00 & 43.00 & 29.00 & 2.60 \\
\hline SA 100 (mg l-1) & 70.00 & 45.00 & 31.00 & 2.80 \\
\hline Si 50 $\mathbf{m g ~ I - 1 ) ~}$ & 71.00 & 45.00 & 30.00 & 2.20 \\
\hline Si 100 (mg I-1) & 78.00 & 46.00 & 35.00 & 2.50 \\
\hline GA3 100 (mg l-1) & 62.00 & 48.00 & 35.00 & 2.30 \\
\hline GA3 200(mg l-1) & 61.00 & 46.00 & 36.00 & 2.50 \\
\hline L. S. D. at 5 \% & 3.20 & ns & 3.20 & 0.19 \\
\hline
\end{tabular}

Concerning, the relative increases mean values of $\mathrm{Fe}, \mathrm{Zn}, \mathrm{Mn}$ and $\mathrm{Cu}$ concentration in leaves maize plant as plants treated with Si rates of (50 and $100 \mathrm{mg} \mathrm{L}^{-1}$ ) were 12.38 and $43.81 \%$ for $\mathrm{Fe} ; 5.36$ and $10.71 \%$ for $\mathrm{Zn} ; 39.70$ and $45.60 \%$ for $\mathrm{Mn}$ and 20.60 and $52.94 \%$ for $\mathrm{Cu}$, respectively compared with control, while the relative increases mean values of $\mathrm{Fe}, \mathrm{Zn}, \mathrm{Mn}$ and $\mathrm{Cu}$ concentration in leaves maize plant as plants treated with GA3 rates of (100 and $200 \mathrm{mg} \mathrm{L}^{-1}$ ) were 12.50 and $19.05 \%$ for $\mathrm{Fe} ; 3.57$ and $7.14 \%$ for $\mathrm{Zn}$; 17.65 and $33.82 \%$ for $\mathrm{Mn}$ and 29.41 and $41.17 \%$ for $\mathrm{Cu}$, respectively, compared with control.

It is evident from the concentration distribution patterns of $\mathrm{Fe}, \mathrm{Zn}, \mathrm{Mn}$ and $\mathrm{Cu}$ in leaves maize that it could be arranged into following orders:

$\mathrm{Si}>\mathrm{SA}>\mathrm{GA} 3>$ control for $\mathrm{Fe}, \mathrm{Zn}, \mathrm{Mn}$ and $\mathrm{Cu}$ of rate $\left(100 \mathrm{mg} \mathrm{L}^{-1}\right)$.

$\mathrm{SA}>\mathrm{GA} 3>\mathrm{Si}>$ control for $\mathrm{Fe}$ and $\mathrm{Cu}$ of rate $\left(50 \mathrm{mg} \mathrm{L}^{-1}\right)$.

$\mathrm{SA}>\mathrm{Si}>\mathrm{GA} 3>$ control for $\mathrm{Zn}$ and $\mathrm{Mn}$ of $\left(50 \mathrm{mg} \mathrm{L}^{-1}\right)$.

On the other hand, the relative increases of mean values $\mathrm{Fe}, \mathrm{Zn}, \mathrm{Mn}$ and $\mathrm{Cu}$ concentration in grains maize plants as affected SA foliar application at rate (50 and $100 \mathrm{mg} \mathrm{L}^{-1}$ ) were 22.64 and $32.07 \%$ for $\mathrm{Fe}$; 2.38 and $7.14 \%$ for $\mathrm{Zn}$; 20.83 and $29.17 \%$ for $\mathrm{Mn}$ and 44.44 and $55.55 \%$ for $\mathrm{Cu}$, respectively, 
compared with control, while the relative increases mean values concentration of $\mathrm{Fe}, \mathrm{Zn}, \mathrm{Mn}$ and $\mathrm{Cu}$ in grains maize plants as affected $\mathrm{Si}$ foliar application at rate (50 and $100 \mathrm{mg} \mathrm{L}^{-1}$ ) were 33.96 and $47.17 \%$ for $\mathrm{Fe}$; 7.14 and $9.52 \%$ for $\mathrm{Zn} ; 25.00$ and $45.83 \%$ for $\mathrm{Mn}$ and 22.22 and $38.89 \%$ for $\mathrm{Cu}$, respectively compared with control. As well as, the relative increases of mean values $\mathrm{Fe}, \mathrm{Zn}, \mathrm{Mn}$ and $\mathrm{Cu}$ concentration in grains maize plants as affected GA3 foliar application at rate $\left(100\right.$ and $\left.200 \mathrm{mg} \mathrm{L}^{-1}\right)$ were 16.98 and $15.10 \%$ for $\mathrm{Fe} ; 14.28$ and $9.52 \%$ for $\mathrm{Zn} ; 45.83$ and $50.00 \%$ for $\mathrm{Mn}$ and 27.78 and $38.89 \%$ for $\mathrm{Cu}$ compared with control , respectively. The relative increases of the studied micronutrients ( $\mathrm{Fe}, \mathrm{Zn}, \mathrm{Mn}$ and $\mathrm{Cu}$ )concentration in grains maize plant are mainly depend on the used SA, Si and GA3 foliar application , as it could be arranged as followa :

$\mathrm{Si}>\mathrm{SA}>\mathrm{GA} 3>$ control for $\mathrm{Fe}$ and $\mathrm{Zn}$.

$\mathrm{GA} 3>\mathrm{Si}>\mathrm{SA}>$ control for $\mathrm{Mn}$.

$\mathrm{SA}>\mathrm{GA} 3>\mathrm{Si}>$ control for $\mathrm{Cu}$ at rate $\left(50 \mathrm{mg} \mathrm{L}^{-1} \mathrm{SA}, \mathrm{Si}\right)$ and $\left(100 \mathrm{mg} \mathrm{L}^{-1}\right)$ of GA3.

$\mathrm{GA} 3>\mathrm{Si}>\mathrm{SA}>$ control for $\mathrm{Cu}$ at rate of $\left(100 \mathrm{mg} \mathrm{L}^{-1}\right) \mathrm{SA}$, Si and $\left(200 \mathrm{mg} \mathrm{L}^{-1}\right.$ ) of GA3. These results are agreement by Tuna, et al (2008) foliar application of GA3 led to increased micronutrient levels in maize plant. Gunes et al (2007) concluded that addition of SA to maize plants grown under salinity increased $\mathrm{Fe}, \mathrm{Mn}$ and $\mathrm{Cu}$ concentration in plant leaves. Also, Levent et al (2007) found that foliar application of $2 \mathrm{mM} \mathrm{SA}$ increased Fe, Mn, Zn and $\mathrm{Cu}$ concentration in leaves maize under salt stressed conditions.

Finally, it is concluded that the concentrations of micronutrients in maize plants, generally, affected increase rates of rate SA, Si and GA3 foliar application.

\section{Chlorophyll content.}

Salinity causes the inhibition of pigments due to instability of protein complex and distribution chlorophyll pigments by inducing the activity of chlorophyllase degrading enzyme, (Pesserakli and Huber (1987).

Table (8) show that the chlorophyll $(a+b)$ and carterniod contents were significantly increased due to application of AS, AG3 and $\mathrm{Si}$, when compared to control. The relative increases of mean values of total chlorophyll $(a+b)$ were $28.23 \%$ and $42.65 \%$ for plant treated by SA at rate $\left(50\right.$ and $100 \mathrm{mg} \mathrm{L}^{-}$ $\left.{ }^{1}\right)$; $15.88 \%$ and $42.10 \%$ plant treated by Si at rate $\left(50\right.$ and $\left.100 \mathrm{mg} \mathrm{L}^{-1}\right)$ and $16.76 \%$ and $36.18 \%$ for plant treated by GA3 at rate $\left(100\right.$ and $\left.200 \mathrm{mg} \mathrm{L}^{-1}\right)$ compared with control. These results are agreement with Afroz et al (2005) who found that inhibition in chlorophyll biosynthesis and reduced chlorophyll content in salt stressed sorghum and maize plants, respectively. GA3 -treated plants exhibited higher values of chlorophyll than did the control or salinitytreated samples. Biglary et al (2011) showed that chlorophyll content was increased with the application of silicon compared to the control. Khodry (2004) and Levent et al. (2007) reported that application of SA to maize plants under salt stress increased total chlorophyll when compared to untreated plant. Ali et al. (2009) pointed out that silicon application significantly increased chlorophyll content of wheat and bean grown under salt stressed soil. Enhancing effect of As, GA3 and $\mathrm{Si}$ on photosynthetic 
capacity could be attributed to stimulatory effect on rublsco contents (Khodary, 2004).

Table (8). The effect of salicylic acid, gibbrillic acid and silicon on chlorophyll and carotene contents in leaves of maize grown in salt affected soil, combined over the two seasons.

\begin{tabular}{|l|c|c|c|c|}
\hline \multicolumn{1}{|c|}{ Treatments } & $\begin{array}{c}\text { Chlorophyll (a) } \\
\mathbf{m g} / \mathbf{g} \text { f.w }\end{array}$ & $\begin{array}{c}\text { Chlorophyll (b) } \\
\mathbf{m g} / \mathbf{g} \text { f.w }\end{array}$ & $\begin{array}{c}\text { Chlorophyll } \\
\mathbf{( a +} \mathbf{b}) \\
\mathbf{m g} / \mathbf{g} \text { f.w }\end{array}$ & $\begin{array}{c}\text { Carotene } \\
\mathbf{m g} / \mathbf{g ~ f . w}\end{array}$ \\
\hline Control & 2.10 & 1.30 & 3.40 & 0.98 \\
\hline SA 50 (mg l-1 & 2.85 & 1.51 & 4.30 & 1.25 \\
\hline SA 100 (mg l-1) & 2.95 & 1.90 & 4.85 & 1.60 \\
\hline Si 50 (mg l-1) & 2.51 & 1.43 & 3.94 & 1.39 \\
\hline Si 100 (mg l-1) & 2.93 & 1.90 & 4.83 & 1.73 \\
\hline GA3 100 (mg l-1) & 2.62 & 1.35 & 3.97 & 1.30 \\
\hline GA3 200(mg l-1) & 2.95 & 1.68 & 4.63 & 1.45 \\
\hline L. S. D. at 5 \% & 0.35 & 0.11 & 0.35 & 0.12 \\
\hline
\end{tabular}

The highest carteniod content was achieved due to in $100 \mathrm{mg} \mathrm{I}^{-1} \mathrm{SA}$. On the other hand, the effect of SA, Si and GA3 different rates foliar application on maize plants were significant on carotene. The photosynthesis is a major controlling of reaction for plant growth and yield. The relative increases of the studied carteniod in maize plant content is mainly depend on the used $\mathrm{SA}, \mathrm{Si}$ and GA3 foliar application, as it could be arranged as follow : $\mathrm{Si}>\mathrm{GA} 3>\mathrm{Si}$ $>$ control at rate $50 \mathrm{mg} \mathrm{L}^{-1}$ for $\mathrm{Si}$ and SA and at rate $100 \mathrm{mg} \mathrm{L}^{-1}$ for GA3. SA $>\mathrm{Si}>\mathrm{GA} 3>$ control at rate $100 \mathrm{mg} \mathrm{L}^{-1}$ for Si and SA and at rate $200 \mathrm{mg} \mathrm{L}^{-1}$ for GA3, respectively, compared with control. These results are agreement by Digdem et al (2007) reported that the SA foliar application was increased pigments content, chl $\mathrm{a}, \mathrm{b}$ and carotenoids under salinity conditions. Moreover, Khan et al. (2003) showed that SA increased photosynthetic rate in corn and soybean.

\section{Conclusion.}

$\mathrm{SA}, \mathrm{Si}$ and GA3 foliar application on maize productivity under saline conditions was significant increased and its nutrients contents and chlorophyll and Carotene contents of leaves and suggest that SA, Si, and GA3 could be used as potential growth regulator to improve plant growth and nutrient utilization under salt stress. These may be depending on the plant species and further research is needed to confirm our results.

\section{REFERENCES}

Abou-Baker , N. H. ; Abd-Eladl. M. and Mohsen, M. A. (2011). Use of silicate and different cultivation practices in alleviating salt stress effect on bean plants. Aust. J. Basic \& Applied. 5 (9): 769 - 781.

Afroz, Sh.; Mohammad, F.; Shamsul, H. and Manzer, H. S. (2005). Exogenous application of gibberellic acid counteracts the effect of sodium chloride in mustard. Turk. J. Biol. (29): $233-236$. 
Al-Harbi, A. R. (1995). Growth and nutrient composition of tomato and cultivar seedlings as affected by sodium chloride salinity and supplemental calcium. J. Plant . Nutr. (18): 1403- 1416.

Ali, A.; Bsra, S.M. Ahmed, R. and Wahid, A. (2009). Optimizing silicon application to improve salinity tolerance. J. Soil and Invir. (2): 136- 144.

Alpislan, M. and Gunes, A. (2001). Interactive effects of boron and salinity stress on the growth, membrane permeability and mineral composition of tomato and cucumber plants. Plant soil, J. (23 b): $123-128$.

Ashraf, M. ; Karim, F. and Rasul, E. (2002). Interactive effects of gibberellic acid (GA3) and salt stress on growth, ion accumulation and photosynthetic capacity of two spring wheat (Triticum aesitivum L. ) cultivars differing in salt tolerance. J. Plant growth Regul. (36): 49- 59.

BeJaoui, M (1989).Interaction between $\mathrm{NaCl}$ and some phytohormones on sugarbeet growth . J. Plant Physiol. (120): 95- 110.

Bengu, T. (2012). Effect of salicylic and gibberllic acids on wheat (Triticum aestivum L.) under salinity stress. Bangladesh. J . Bot. 41 (1): $29-34$.

Berthelsen, S.; Noble, A.D. and Garside, A.L. ( 1999). An assessment of soil and plant silicon levels in North Queensland. In: Proceedings Australian Society of Sugar Cane Technologists, 21: 92-100.

Bhupinder, S. and Usha, K. (2003).Salicylic acid induced physiological and biochemical changes in wheat seedlings under stress. Plant Growth Regul. (39): 137- 141.

Biglary, F.; Haddsad, R. ; Hosseini , R. and Sotudehniya, A. (2011). Roles of silicon in improving oxidative stress resistance by increase of chlorophyll content and relative water content of rice (Oryza sativa L.) genotypes. Proceedings of the $5^{\text {th }}$ International Conference on Silicon in Agriculture. September 13-18. Beijing. China.

Black, C. A. (1965) "Methods of soil analysis." Soil Science Society of American Inc. Publisher, Madison, Wisconsin, U.S.A.

Botella, M. A.; Martinez, V.; Pardines, J. and Cerda, A. (1997). Salinity induced potassium deficiency in maize plant. J. Plant Physiol. (150): 200- 205.

Chapman, H.D. and Pratt, P.F. (1961), "Methods of analysis for soils, Plants and Water." Agric. Publ. Univ., of California,Reverside.

Champagneil, F. (1979). Relation between phosphate nutrient of plant and salt toxicit. Agric. J. (79) : $35-43$.

Chowdhury, M. A. and Sawar, A. K. (2000). Effect of gibberellic acid and soil salinity on germination, yield and yield components of maize (Zea mays L.). J. Agric Sci . 33 (3/4): 115 - 122.

Cottenie, A.; verloo, M.; Velghe, G. and Cameriynck, R. (1982) "Chemical Analysis of plant and soil." Laboratory of analytical and Agrochemistry, State Univ., Ghent, Belgium.

Cram, W. J. (1983). Chloride accumulation as homeostatic system set points and perturbation . J. Exp. Bot. (34): $1484-1502$.

Digdem, K.; Mehmet, Y. and Neso, K. (2007). Effects of salicylic acid on the growth and some physiological chareacters in salt stressed wheat (Triticum aestivum L.) Tarim Billmlerl Dergisi. 13 (2): 114- 119. Ankara. 
Doering, H. W.; Schulze, G. and Rocher, P. (1984). Salinity effect on micronutrient supply of plants differing in salt resistance In: Proceeding of the Sixth International Colloquium for optimization of plant nutrition, Montpellier, France : $165-172$.

Fahad, S. and Asha, B. (2012). Effect of salisylic acid on physiological and biochemical characterization of maize grown in saline area. Pak. J. Bot. , 44 (4): 1433- 1438

Farahbakhsh, H and Shamsaddin, S. (2010).Effect of foliar application of salicylic acid on vegetation growth of maize under saline conditions. J. Plant and Physiology. (2): 27- 30.

Gharib, A.A. and Hanafy, A.H.( 2005). Response of pea plants (Pisum sativum L.) to foliar application of putrescine, glucose, foliafeed $D$ and silicon. J. of Agric. Sci. Mansoura Univ. (30): 7563-7579.

Gunes, A.; Inal ,A.; Alpaslan, M.; Eraslan, F.; Bagci, E.G. and Cicek, N. (2007). Salicylic acid induced changes on some physiological parameters symptomatic for oxidative stress and mineral nutrition in maize (Zea mays L.) grown under salinity. J. Plant Physiol., 164: 728736.

Hadi, F. ; Bano, A. and Fuller, M. P. (2010). The improved phyto-extraction of leas $(\mathrm{Pb})$ and the growth of maize (Zea Mays L.): The role of plant growth regulators (GA3 and IAA) and EDTA alone and in combinations. J. Chemosohere. (80): $457-462$.

Hanafy, A.H.; Harb, E.M. ; Higazy, M.A. and Morgan, Sh.H. (2008). Effect of silicon and boron foliar applications on wheat plants grown under saline soil conditions. Inter. J. Agric. Res., 3(1): 1-26.

Hasan, F. and Mohaddeseh, S. (2011).Effect of foliar application of salicylic acid on vegetative growth of maize under saline conditions. Afric.J. Plant Sci. 5 (10): $575-578$.

Hawkins, H. S. and Lewis, O. A. (1993). Effect of $\mathrm{NaCl}$ salinity, nitrogen form , calicium and potassium concentration on nitrogen uptake and kinetics in Triticum aestivum, L. New Phytol. (124): $171-177$.

lqbal, M., Ashraf, M, (2010). Gibberellic acid mediated induction of salt tolerance in wheat plants: Growth, ionic partitioning, photosynthesis,

yield and hormonal homeostasis. J. Environ Exp. Bot., (in press).

Jackson, M.L (1967). "Soil chemical analysis". Constable and Co. L.T.P., London, England.

Khan, W.; Balakrishnan, P and Smith, D.L. (2003). Photosynthetic responses of corn and soybean to foliar application of salicylates. Journal of Plant Physiology 160 (5): 485-492.

Khodary, S. E. (2004). Effect salicylic acid on the growth, potosysynthesis and carbohydrate metabolism in salt stressed maize plant. Inter. J. Agric. Biol. (1): 5- 8.

Klessing, D. F. and Malamy, J. (1994). The salicylic acid signal in plants. Plant and Bio. (26): 1439- 1458.

Kothule V.G.; Bhalerao R. K. and Rathod T. R. (2003). Effect of growth regulators on yield attributes, yield and correlation coefficients in soybean. Annals Plant Physiol., 17(2):140-142. 
Levent, T.; Cengiz, K.; Murat, D. and David, H. (2008 b). The combined effects of gibberellic acid and salinity on some antioxidant enzyme activities, plant growth paramerters and nutritional status in maize plants. Envi \& Exper. Biot. 62 (1): $1-9$.

Levent, A. ; Kaya, C. ; Dikilitas, M. ; Yokas, J. ; Buruo , B. and Altunlu, H. (2007). Comparative effect of various salicylic acid derivatives on key growth parameters and some enzyme activities in salinity stressed maize (Zea mays L) plants. Pak. J. Bot. 39 (3): 787- 798.

Liang, Y.C.; Chen, Q.; Liu, Q.; Zhang, W.H. and Ding, R. X. (2003). Exogenous silicon (Si) increases antioxidant enzyme activity and reduces lipid peroxidation in roots of salt-stressed barley (Hordeum vulgare L.). J. Plant Physiol. 160: 1157-1164.

Liang, Y.; Zhang, W. and Ding, R. (2005). Effect of silicon on $\mathrm{H}^{+}$ATPase and $\mathrm{H}^{+}$Pase activity, fatty acid compostion and fluidity of tonoplast vessel from roots of salt stressed barley (Hardeum vulgare. L.) . J Enviro. Ex. Bot. (53): $29-37$.

Lichtenthaler, H.K. (1987). Chlorophylls and carotenoids pigments of photosynthetic biomenranses. Methods Enzymol (148) : 350- 382.

Lindsay, W.L. and Norvell, W.A. (1978). Development of a DTPA soil test for $\mathrm{Zn}, \mathrm{Mn}, \mathrm{Fe}$ and $\mathrm{Cu}$. Soil Sci. Soc. Am. J., 24(2): 421-428.

Mady, M. A. (2009). Effect of foliar application with salicykic acid and vitamin $\mathrm{E}$ on growth and productivity of tomato (Lycopersicon esculentum, Mill) plant. J. Agric. Mansoura Univ. 34 (6): 6735 - 6746.

Moussa, H. R. (2006). Influence of oxegenous application of silicon on physiological response of salt stressed maize (Zea mays L.). J. Agric. Biol. (8): 293- 297.

Mukkram, A. T. ; Rahmatullah, M. ; Tariq, A.; Ashraf, M.; Shamsq, K. and Maqsood, M. A. (2006).Beneficial affects of silicon in wheat (Triticum asstivua L.) under salinity stress . Pak, J. Bot. (38): 1715- 1722.

Naeem, M.S; Jin, L.; Wan, G.L.; Liu, D. and Liu, H.B. (2010). Aminolevulinic acid improves photosynthetic gas exchange capacity and ion uptake under salinity stress in oilseed rape (Brassica napus L.). Plant Soil, 332: 405-415.

Page, A. L. ; Miller, R.H. and Keeney, D. R. (1982). Methods of soil analysis .II., Chemical and Microbiogical properties $2^{\text {nd }}$ Ed. Madison, Wisconsim . U.S.A.

Page, A.L., Chang, A.C. and Adriano, D.C., (1990). Deficiencies and toxicities of trace elements. Agricultural Salinity Assessment and Management, Chapter 7, ASCE Manuals and Reports on Eng. Practice No. 71, ASCE, pp. 138- 160.

Parida, A. K. and Das, A. B. (2005). Salt tolerance and salinity effect on plants. A review. Ecotoxicology and Environmental Safety, (60): 324349.

Pei, Z.F.; Ming, D.F.; Liu, D. ; Wan, G.L. ; Geng, X .X.; Gong, H.J.and Zhou, W.J .(2010). Silicon improves the tolerance to water-deficit stress induced by polyethylene glycol in wheat (Triticum aestivum L.) seedlings. J. Plant Growth Regul. 29: 106-115. 
Pesserakli, M. and Huber, J. T. (1987). Dry matter, yield, nitrogen absorption, and water uptake by sweet corn under salt stress. J. Plant . Nutr. (12): 279- 290.

Piper, C.S. (1950) "Soil and Plants analysis." A monograph from the water. Agric. Res. Inst., Univ. of Alediade, Australia.

Romero, A.; Jourado, M. and Cuartero, J. (2006). Silicon alleviates the deleterious salt affects on tomato plant growth by improving plat water status. J. Plant Phys. 163 (8): 847- 855.

Ruiz, D. ; Martoanaz, V. and Cerda, A. A. (1997). Citrus response to salinity growth and nutrient uptake. J. Tree Physiol. (17): $141-150$.

Shu, L. Z. and Lui, Y. H. (2001). Effect of salian on growth of maize seedlings under salt stress . Agro. Enver. Port, (20): 38- 40.

Singh, K.; Singh, R.; Singh, J.P. ; Singh, Y. and Singh, K.K. (2006). Effect of level and time of silicon application on growth, yield and its uptake by rice (Oryza sativa). Indian J. Agric.Sci., 76(7): 410-413.

Snedecor, G.W. and W. G. Cochran (1990). "Statistical Methods $7^{\text {th }}$ ed . IOWA, State Univ. U.S.A.

Soliman, M.S. and Doss, M. (1992). Salinity and mineral nutrition effects on growth and accumulation of organic and inorganic ions in two cultivated tomato varieties. J. Plant Nutrition 15:2789-2799.

Soltan, P. N. (1985) Use of ammonium bicarbonate- DTPA soil tests to evaluate elemental availability and toxicity. "Soil Sci. Plant Anal., 16 (3): $323-338$.

Troudia, A. ; Bouaziza, H.; Soudania, N.; Amara, I. B.; Boudawara, T.; Touzanic, H.; Lyoussid, B. and Zeghal, N. (2012). Neurotoxictivity and oxidative stress induced by gibberellic acid in rates during late pregnancy and early postnatal periods: Biochemical and histological changes. Exper. Toxicol. Pathol. (64) : 583- 590.

Tuna, A. L.; Kaya, C. ; Dikilitas, M. ; and Divid, E. (2008). The combined effect of gibberlic acid and salinity on some antioxidant enzyme activities, plant growth parameters and nutritional status in maize plants. Environmental and Experimental Botany. 62 (1): 1- 9.

Wen, F.P.; Zhang, Z.H. ; Bai, T. ; Xu, Q. and Pan, Y. H. (2010). Proteomics reveals the effects of gibberellic acid (AG3) on salt stressed rice (Oryza sativa L.) shoots. Plant . Sci. (178): 170- 175.

Yamane, K.; Rahman, M.S.; Kawaski, M. and Tniguchi M.H. (2004). Pretreatment with antioxidants decreases the effects of salt stress on chloroplast ultra-structure in rice leaf. Plant Prod. Sci., 7: 292-300.

Zhukovskaya, N. V. (1973). Phosphate uptake and accumulation by the plants under conditions of soil salinization. Fizoil. Res. (20): 71-78. 
كفاءه استخدام حمض السيلسيك وحمض الجبريلك والسليكون على انتاجية الذره تحت ظروف الأراضى المتاثرة بالاملاح

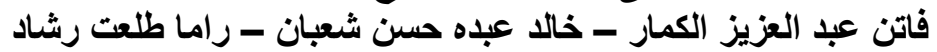

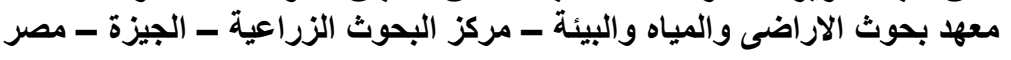

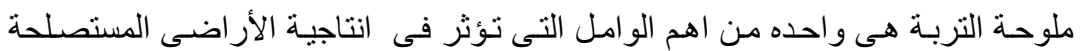

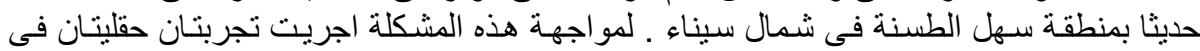

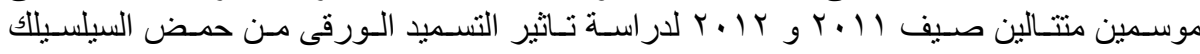

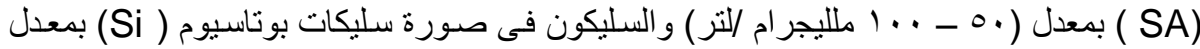

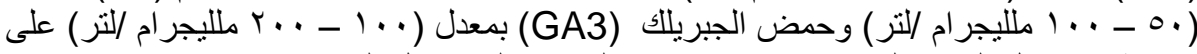

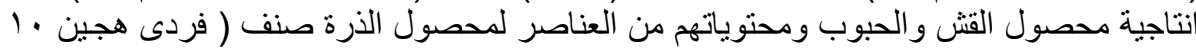

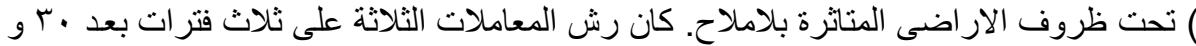

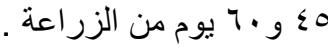

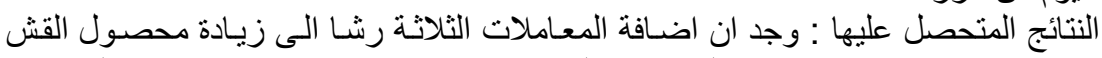

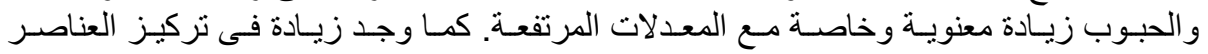

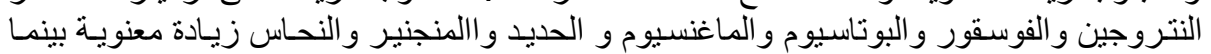

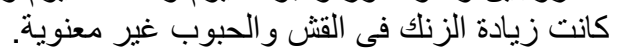

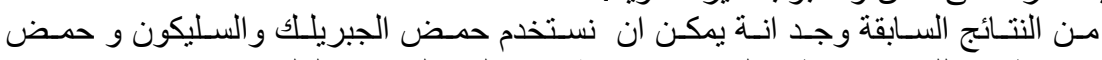
السليسيلك كمنظمات للنمو ومنشطات لتحسين مقاومة نبات الذرة للاجهاد الملحى.

كلية الزراعة - جامعة المنصورة كلية الزراعة بمشتهر - جامعة بنهة بلهن
قام بتحكيم البحث

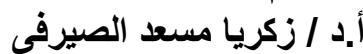

أ. أد / حسن حمزه عباس المبرفي 